Portland State University

PDXScholar

9-1-1969

\title{
A quantification and analysis of verbal interaction between clinician and client in a public school setting
}

Norma C. McAleer

Portland State University

Follow this and additional works at: https://pdxscholar.library.pdx.edu/open_access_etds Let us know how access to this document benefits you.

\section{Recommended Citation}

McAleer, Norma C., "A quantification and analysis of verbal interaction between clinician and client in a public school setting" (1969). Dissertations and Theses. Paper 263.

https://doi.org/10.15760/etd.263

This Thesis is brought to you for free and open access. It has been accepted for inclusion in Dissertations and Theses by an authorized administrator of PDXScholar. Please contact us if we can make this document more accessible: pdxscholar@pdx.edu. 


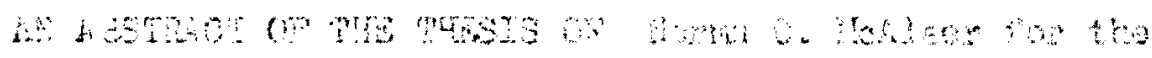

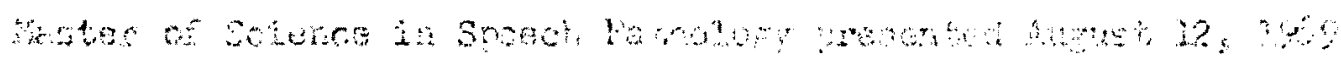

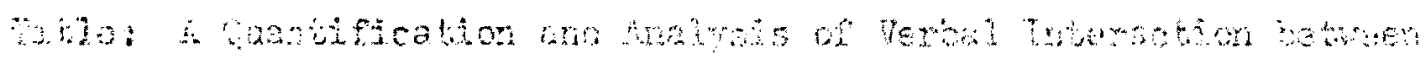

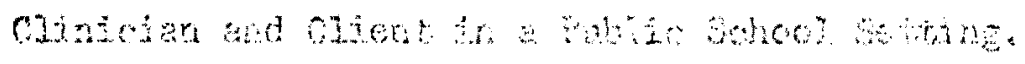

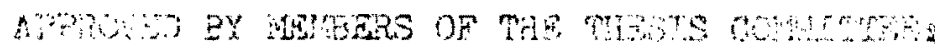
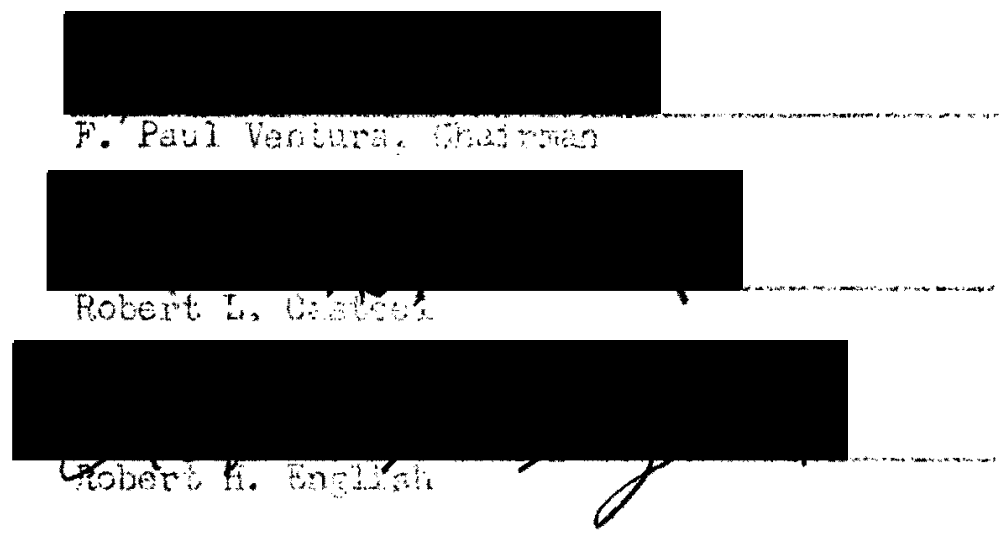

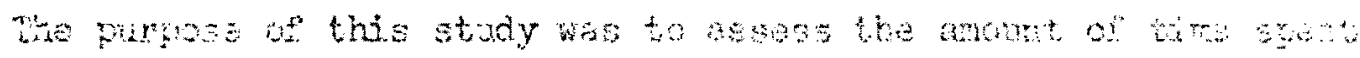

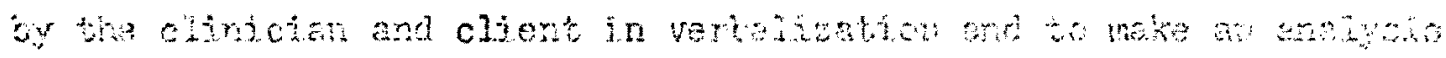

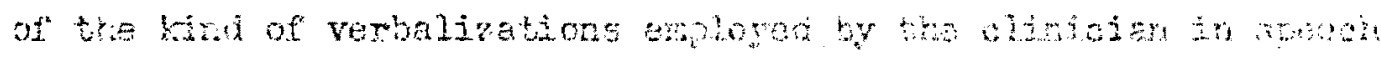

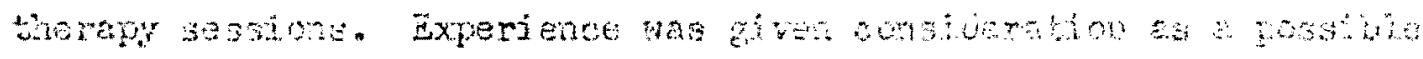
vartabs in the atody.

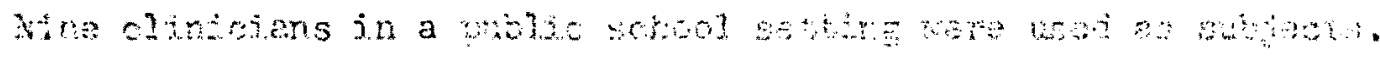

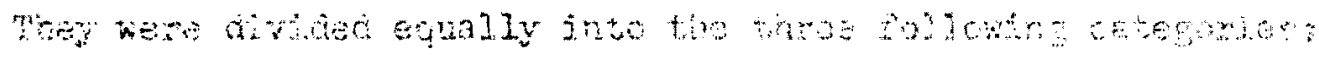

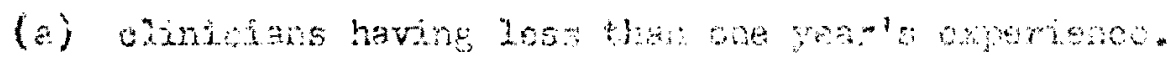

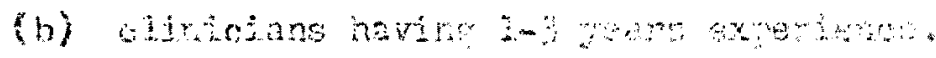

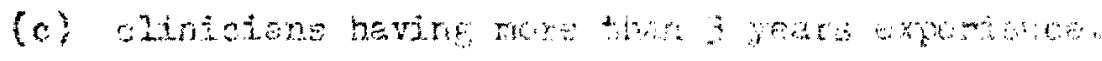

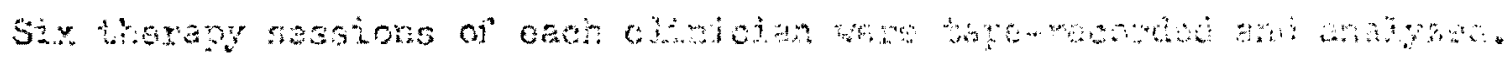


It was found that experterce was rob a stentiont variable in efther of the two categories under study. It wat enown, hovever, that there was a negative correlation batraer the anowh of verbaliation of clinician and client. Hight out of hine dinkiens telked nore than the clients. A higr correlation has notod betwent the amount of verbalization used by the cilitions and thatr use of pesitive and descriptive utterances. The anout of clisut vemblization somed to bear little or no relatjonshe to the kinds of at terances used by the clinician. Analysis of positive err descriptive utterances shored a high positive correlation, while nost of the other categories showed evidence of a moderate negative relationstip.

Further study was suggosted for tha followne:

(a) a survey of the different techniques used by clinfejans

(b) the effect ot different bechnigues or the amount of verbalization used by botic chician and client.

(c) the modificetion of the content of the cibent's responses by the knde of utterances used by the clinj.cian

The present study may be of most valne in indicating a posible neans of constructing a profile of the kinds of wterances weed by ach clinician. 


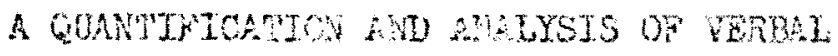

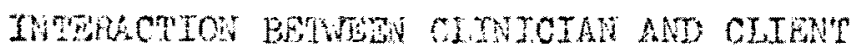

IN A PUILIO SCHOOL, SEITINO

by

NORMA C. YCAJEER

A thesis submitted in partial fulfillment of the requirements for the degree of

MASTER OF SCIENCE

in

SPEECH PATHOIOCY

Portland Statie Univasity

Septeriber 1969 


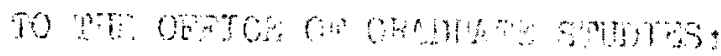

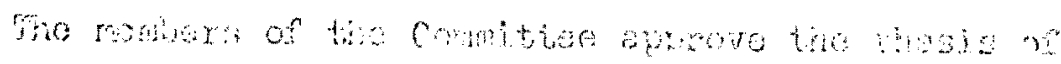

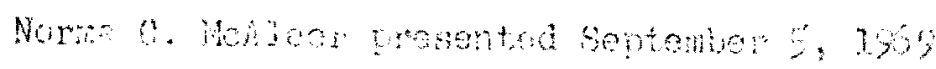
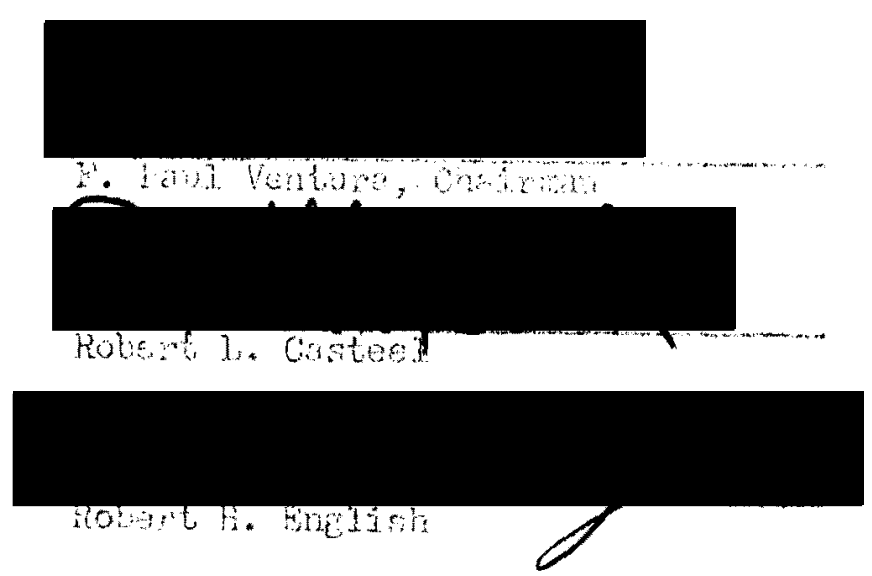

s.1907\%

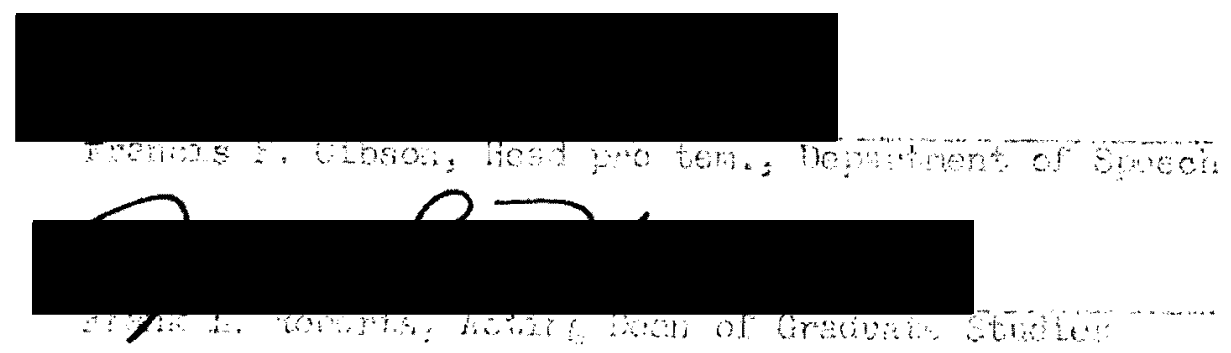

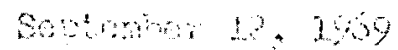




\section{ACRow}

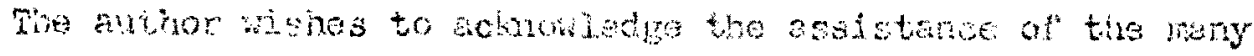

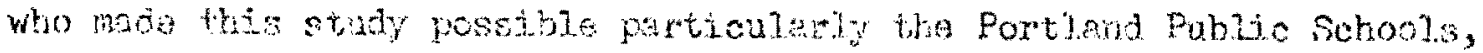

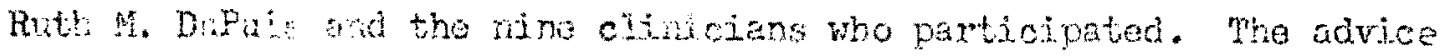

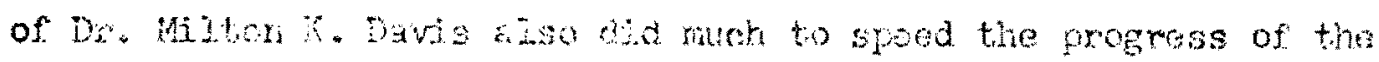
find andysis. The patjont comagration and understaming of no

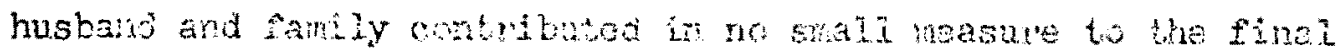

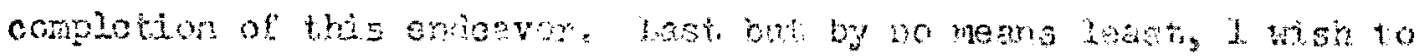

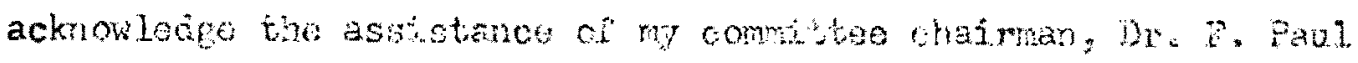

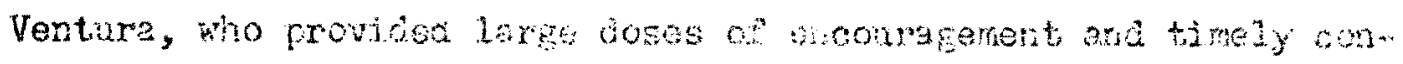
struetive oxitichan along he vay. 
TABIS OH CONRZMTS

PACE.

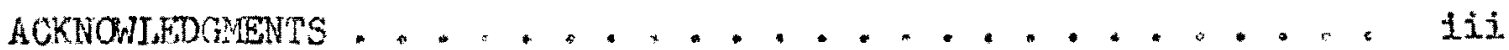

$\operatorname{LTST}$ or TABTES .......................... v v CAATTER

I. INTRODUCTION $, \cdot \cdot \cdot \cdot \cdot, \cdot, \cdot \cdots \cdot \cdot \cdot \cdot \cdot \cdot \cdot \cdot \cdot \cdot \cdot$ I

I. HISTOKY AND STRTEMENT OF THE PROBLEM . . . . . . . . . 3

Statement of the problem ............... 6

III. PROCEOURES. . . . . . . . . . . . . . . . 8

Subjects ...................... 8

Analyede . . . . . . ...............

IV. Drscusstol ........................ $3 \varepsilon^{\ldots}$

v. COMGLUSTONS AID SUMHARY . . ................ 22

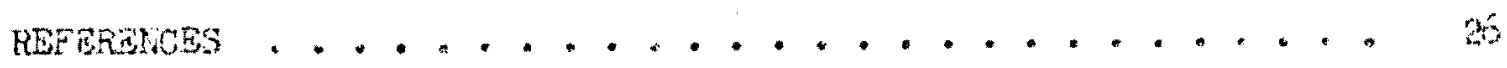
MPPEVIX .............................. 27 


\section{UIST OF PABLES}

TABIE

PAGE

I. Mean percentares of arount of verbelization in six sessions usigg 20 minutes as the averge jength . . . 9

II. Group mean percentages of amount of verbibuation . . . . 9

III. Kinds of utberances represented in averege number per minute ........................ 1 \%

IV. Rank order anajysis of anount of cinioins" verbalization. 13

V. Rank order analysis of arount of clients verbalization . I4

VI. Rank difference arrejatjon betweon amount of verbaitzew

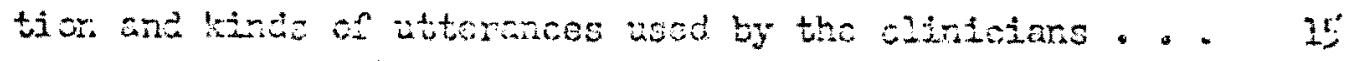

VI. Rank order ariajysis of the number of positive uterences used .................., .........

VIJ. Rank ordar analysis of the number of negative utterances:

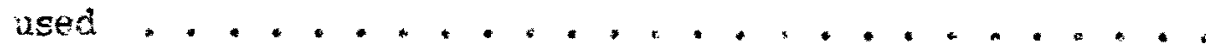

IX. Rank order analysis of the number of cescriptive utterences used .........................

X. Rank ofius analysis of the number of extraneous utterances

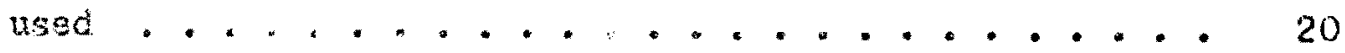

XI. Rank difference coprelation betwenn kinds of utterances. . 21 III. Profiles of clinicians rornalizations . . . . . . . 23 
CHAFTE I

JNTRODUCYION

Progress and amprovenents in any profgssion come about as tho result of roseareh ard revision of contemporem technigues. Sperels clinicians as professionals miy find it of value to do sono stock-taking of what they do in therapy sessions. By modifying their om behavior, perhaps they in turn may find it easies to modify the behavion of their clients. Clinicians have nary acceptable methods that can bo employed in speech therapy sassions, but the mothods way be greatiy modtied in their effectiveness by the manner of prusenteition. Wuch has been writteri about the techiques, methods and skills that the clingian might consider, but investigations about the amount of verbalization the clinician might use in a typical therapy session have been sparso. Verbal interaction is another area that has not been adeguately covered.

The clinfian is larkety frae to use mothods and technigues which seem to him appropriate at the monent. These nay require varying amounta: of verbalization on his part, and sono cifniciens may tend to be more

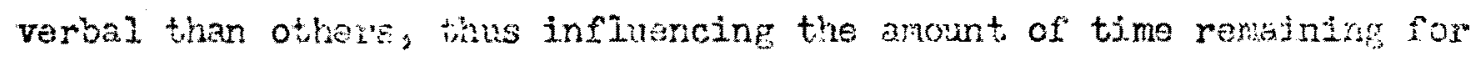
the clionts to protite spech. Furthemore, the kinds of utorances used may play an important part in moiifying the sposeb neherion of the

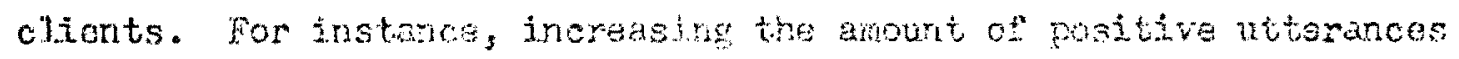

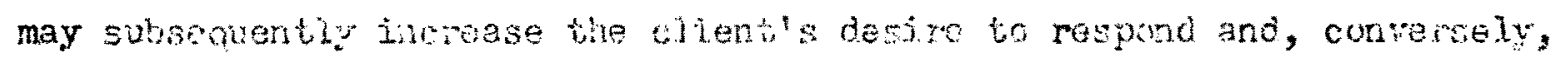

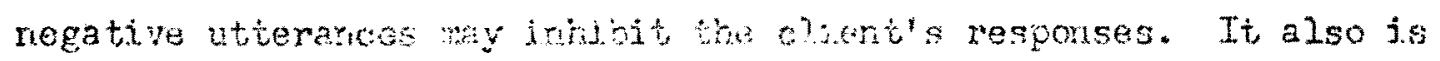


possible that exparience ma prove to re an smotent raniablo in determining the amount and kind of remitisation used. Wh these factors in mind verbal interaction in seech therapy was considered a valid subject for investigation. 
CIIXPritit II

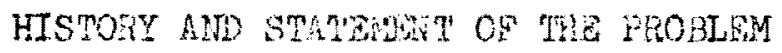

Few studies seem to have bean made conceroing vertal interaction with special references to speech therapy. In raviefing the literature it has been found, howevor, that investigations havo been made with regard to analyzing the verbal interaction in an intewiew situation. It would seen that the speech clinician in a sense is aralagous to the interviewer. Chapple (19/9) attempted to standarize, and therefore nake objective, the interview as a research instrument. He inverted the Interaction Chrorograph which recorded Eraphically the amount of time used for any audible verbalization. It could be usod like a very elaborate elestrical stopsatch," allowing an obsenver to ouantify with a high degree of precision the verbal interaction of two individuals. He found that:

- "not only do different interviewers have different interaction patterns whon behaving in their own characteristic manner, but that, as a result of these interviewer differences, different interaction pattems were elicited from the same patient when seen by two different interviewers.

He suggested that analysis of the time variable during the interview renected personality and devised a method using the Interaction chronograph wheroby the intorview could be standardized. This method since has been reviowed by Matarazzo et al. (1956) and further investigated by Saslow and Natarazzo (1958). Results of an experiment using the standardized method with 20 patients and 2 interviewers would indicate that the interaction variables reflect the specifia nersonality 
differences of the two interviewers.

Goldman and Eislor (1952) desombed how threo doctors influenced the interaction pattems of the sane ten yatients in different ways. Thus, depressed patients talked more with one doctor than anothor while these same doctors had opposite effects or telkative patiants. The author wondered if speech cilnicians might have similer efrects or their clients.

The content and amount of verbalization by the clinician may have a strong effect on the responses of the cljent. As Skinner (1957) puts it: "Verbal behavior is behavior roinforced througt the mediation of other persons." Following this line of thonght, Krasner (1958) used a storyteling technique to study the relationship between examiner behavior cues and patients' verbal behavior. The results indicated that changes in a preselected class of verbaj behavior varied as a function of the systematic applicetion of behavion cues by the examiner. Kanfer and McBrearty (1962) investigated the specific effect of minimal interviewor cues on verbal material obtained in clinical interviews and found that minimal social reinforcement resultod in increased communication on those topias for which it is given.

Phodes, Shames and Figolf (1968) have suggested that, as clinicians, we should provide a clinical situation in which language content is manipulated subtly. Eight subjocts participating in stutterine therapy recesved verbal approval or disapproval following the emission of critical responses about thes stuttering behaviors. Desirable language was positively reinforced. Half' of the subjects were informed which kind of language was heing reinforced whtle half wert not. Results showed that, in both groups, desirabie language increased. 1 was 
suggestod that the use of simian rejnoreanont might be of value as a alinical tool for other speecin ditorders.

Ixter Kanfer (1958) wrote of the increased recognition by inter" viewers of their owr capacity for aystenatically viasing the rate, volume, or content of patient productions. He suggested that this interviewer approach verbal behavion, not as an expression of the interviewer's thought processes, but as interactional behavior which can be systenaticaliy influenced by environmental. variables. Sloane and MacAuiay (1958) further sabstantiated this thinking. They wrote that approaches to understanding, speech and language must be based upon ax environmental analysis in order to have any direct implication for remedial work. The environment created and the part playod by the alinician in a therapy session wuld appear to be important variables in the modification of speech behavior.

Mowrer (1969) believes that the verbal statements used by clinicians as consequent events shoulo be drasticelly recuced.

Clinician statemants tend to be disruptive and of ten lead to the termination of conriected speech. The time consumed in issuing verbal statements competes with the tine during which the child should be responding.

Pilot studies at Arizona State iniversity indicate that the number of correct responses is increased nearly 300 ur cent when a visual displey systen using a buzzi and lights is used instead of verbal statemerts as consequent events in therapr sessions. These studies seem to support the theory that speech clinicians engage in too much varbalization. A study involving seven speech clinicians selected randomly in the metropolitan Pluanix area was recent.ly reported by Mowrer" (1969). A tape-rocoming was male of one therefy sescion of each clinician. The 
verbaliations of both be olinician and clients were thon anslyzed. It was determined that for each uttemare the ciient produced, the clinician produced 10.5. Of the utterances produced by the cients, only .05 per cent contained the souni to be worked on. An analysis of the kinds of verbulizations rovaled that almost half of the cinjecian's instructiona? time was spent in eliciting a sound or nord, usually an echoic utterance. A relatively smajl anount of time was spent jin demonstration cues, listering activities and feedback. Nearly one half of the utterances were in no way related to corraction of misarticulations, auditory training or speech correction in general. The results seem to indicate that clients are rrovjad with extremely few opportunities to emit targot responses during therapy. In adoition it would seem that much irrelevant verbaljzation is permited. However, since the above study involvod a relatively small sample, it would seom aniss to make a sweeping gererajiration about ell clinicians based on these findings. Further research involvirg larger samples seems to be indicated.

\section{STATEMNT OF THE PROBLEM}

This author dealt with only two general aspects of therapy sessions, 1jirst the anount of time spent by the clinician and client in verbalization and second the kind of verbalizations employed by the clinician. This invastigation did not intend to assess the effectiveness of therageutic techniques. Ar attempt was made, however, to compare the morcentage of verbelinations and the type of utterances made by:

(a) Canicians hoving less than one year's experience

(b) Clinicians having $2-3$ jears experience

(c) Cluicians having nore than 3 years experience. 


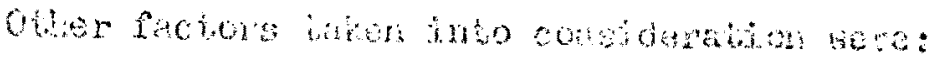

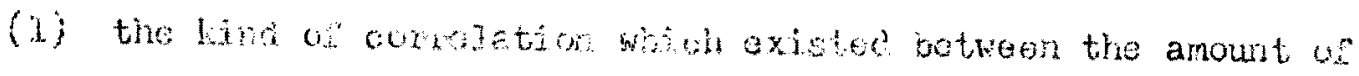

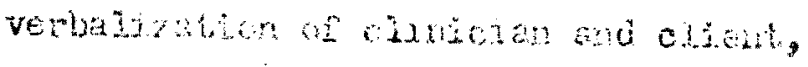

(2) the relationatip of the kimes of utbareness to tist amount of vorblization ky the simbian, sod

(3) the redationitip of the kjuds of witerances used by the cliaticin to the anomt of verbsidiation by tho client. 


\section{CHTHE IT}

\section{TRCENAS}

Subjects:

The subjects in this investigation were nino clinidars from the Portiand, Oregon, Public schools divided equally acomding to the following these groups:

Group I: clinicians having less than one year's experience

Group IJ elinicians having I-3 years of expexience

Group III: clinicians having more than 3 years experience. Six sessions conductod by each of these cliricians worlang in a typinal therapy situation were tape reconded using a craig faje recoxie* Te elementary school students particjpating had been diagnosed as having primarily an articulation problen. The number of students in each session ranged from 1 to 5 with the average consisting of 3 . The sestats varied ir length from 15 minutes to 314 minates, with the aversas ros sisting of 20 minutes. Analysis

The clintcians, the prinary subjectis for this stoly, were each assigned a letter desjenation, those in Grove I (sea chove) being assigned $A, B$ and $O$, group II $D, E$ and $F$ and Group $I X$, , $Y$ and $I$.

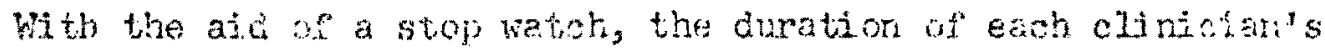
verbalization was recovied, totalled and expressed as a percertares the total time tho sestom lastod. These results dero then conortist

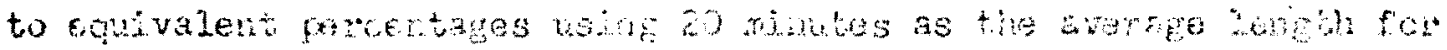


9

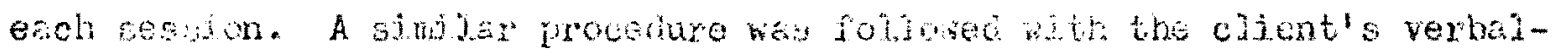

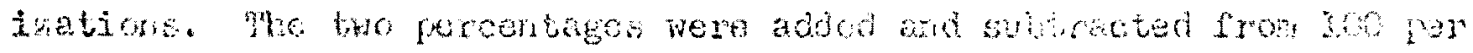
cent and th s provides a percentage indicator of he total tan spent

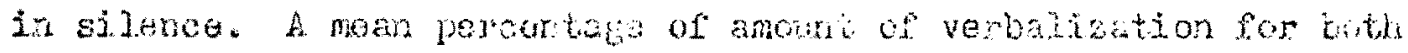

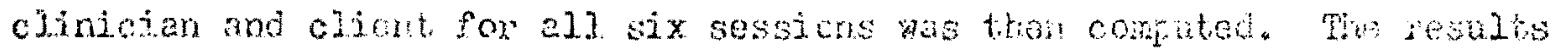
fare listed in liable I.

TABLET

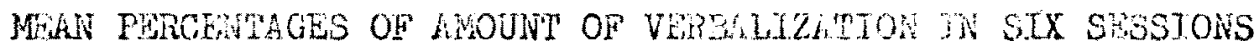
USING TONY MINUTES AS THE AVENGE WROTH

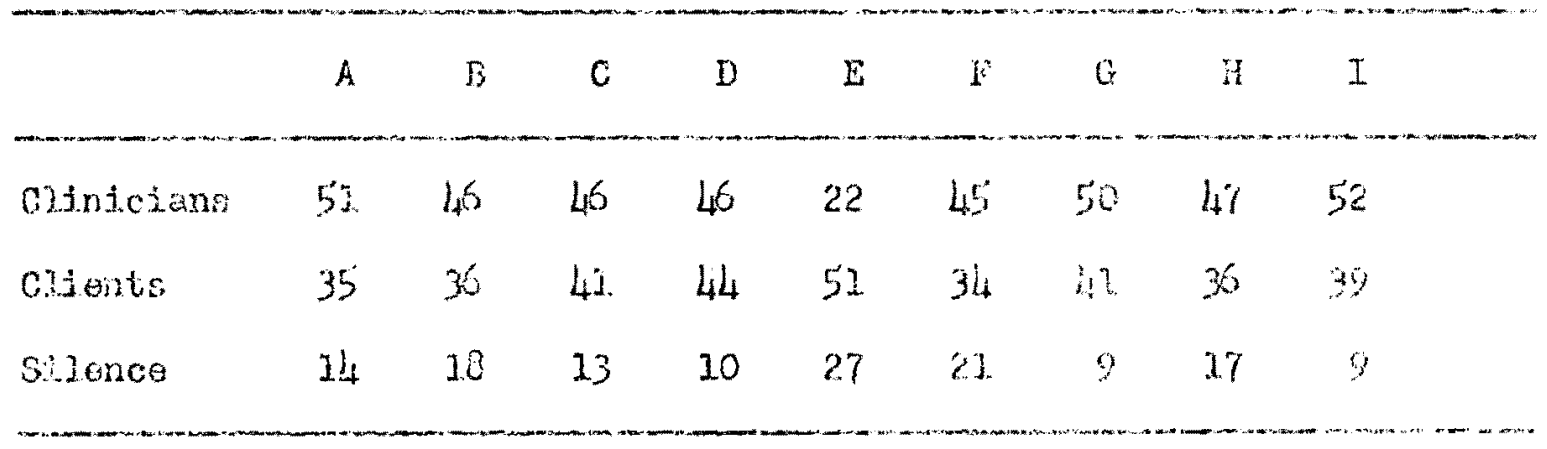

From those results a group roan was derived. Table I chow wa was.

TABLE II.

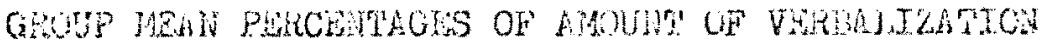

Group I Group $1:$ Grip Tit $(f, B, C) \quad(0,2, B) \quad(1,1,1)$

Oixicians

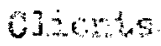

Sizerion
48

37

15
37

43

20
45

35

72 
Five two-minute segnents thosen ot ridon from each sosoion wero used to count the number of uttercices mide by the clinician, these being listed under four catsorios:

(a) positive $(e \cdot b$. good, right, that's rino, that's what we like to hear)

(b) negative (a.g. no, that's wrog, don't do that, I didn't like that)

(c) directive or descriptive (6.g. say. ..., repeat, jook at the picture; any description of placenent of articulators; modelline of sounds or words)

(d) neutral or extraneous (e.g. any remarks about events or objects having no rolationship to the therapy session)

The number of utterances per minute for each session was computed. An everage of utterances per minute under the four categories was then computed fon the six seseion of och eliniction. Those rosults oan bo seen in Table III. 


\section{WHETR III}

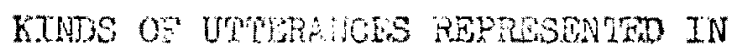

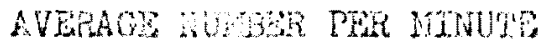

\begin{tabular}{ccccc}
\hline Climician & Positive & Negative & Deseriptive & Extrareous \\
\hline A & 4.6 & .2 & 9.4 & 1.2 \\
B & 4.4 & .6 & 6.2 & .8 \\
C & 2.3 & .3 & 7.1 & 1.2 \\
D & 4.7 & .5 & 7.7 & 1.4 \\
I & .7 & .6 & 2.1 & 2.4 \\
F & 1.8 & .5 & 4.3 & 2.0 \\
G & 5.0 & .3 & 11.9 & .4 \\
H & .9 & 1.0 & 5.4 & .9 \\
I & 2.0 & .7 & 7.9 & \\
\hline
\end{tabular}




\section{$\operatorname{con} 2 \mathrm{~min}$}

\section{nucussion}

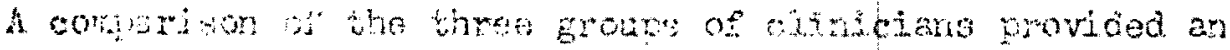

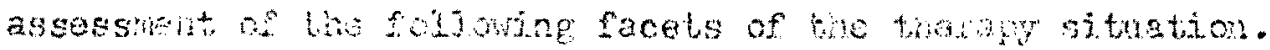

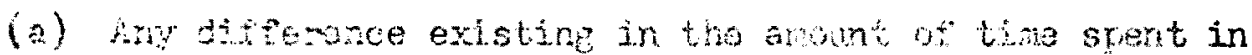
rerbaitiation.

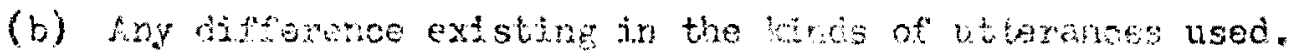

In contox the reans ot each of the throe groups tor both (a) the amound of tym suats in verbalization and (b) the kinds of

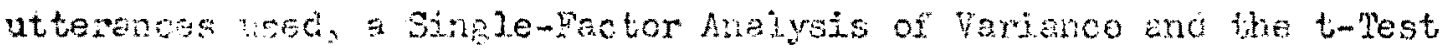

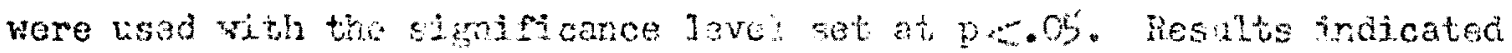

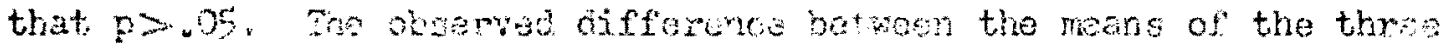

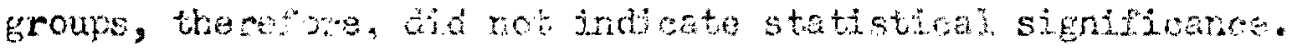

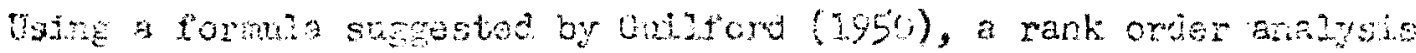

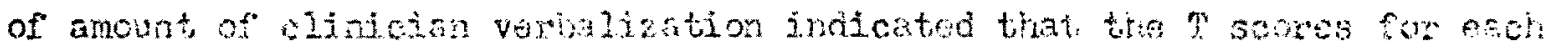

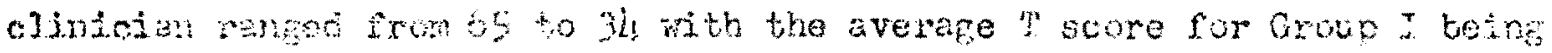

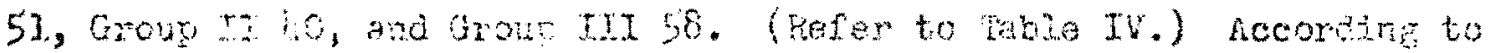

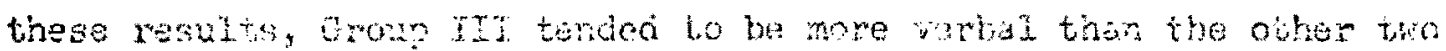

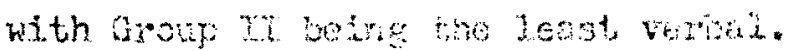

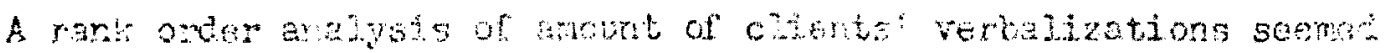

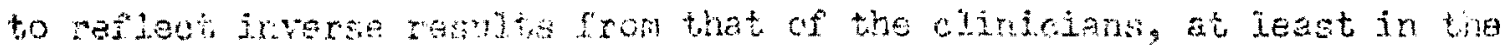

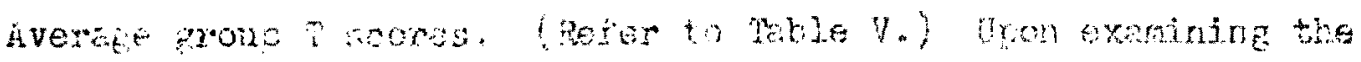

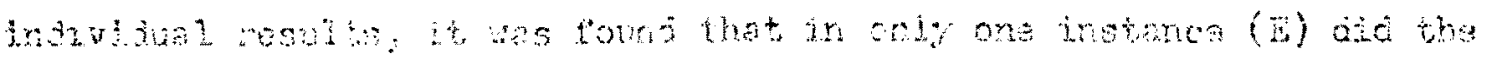


mo, 16

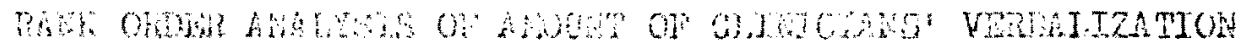

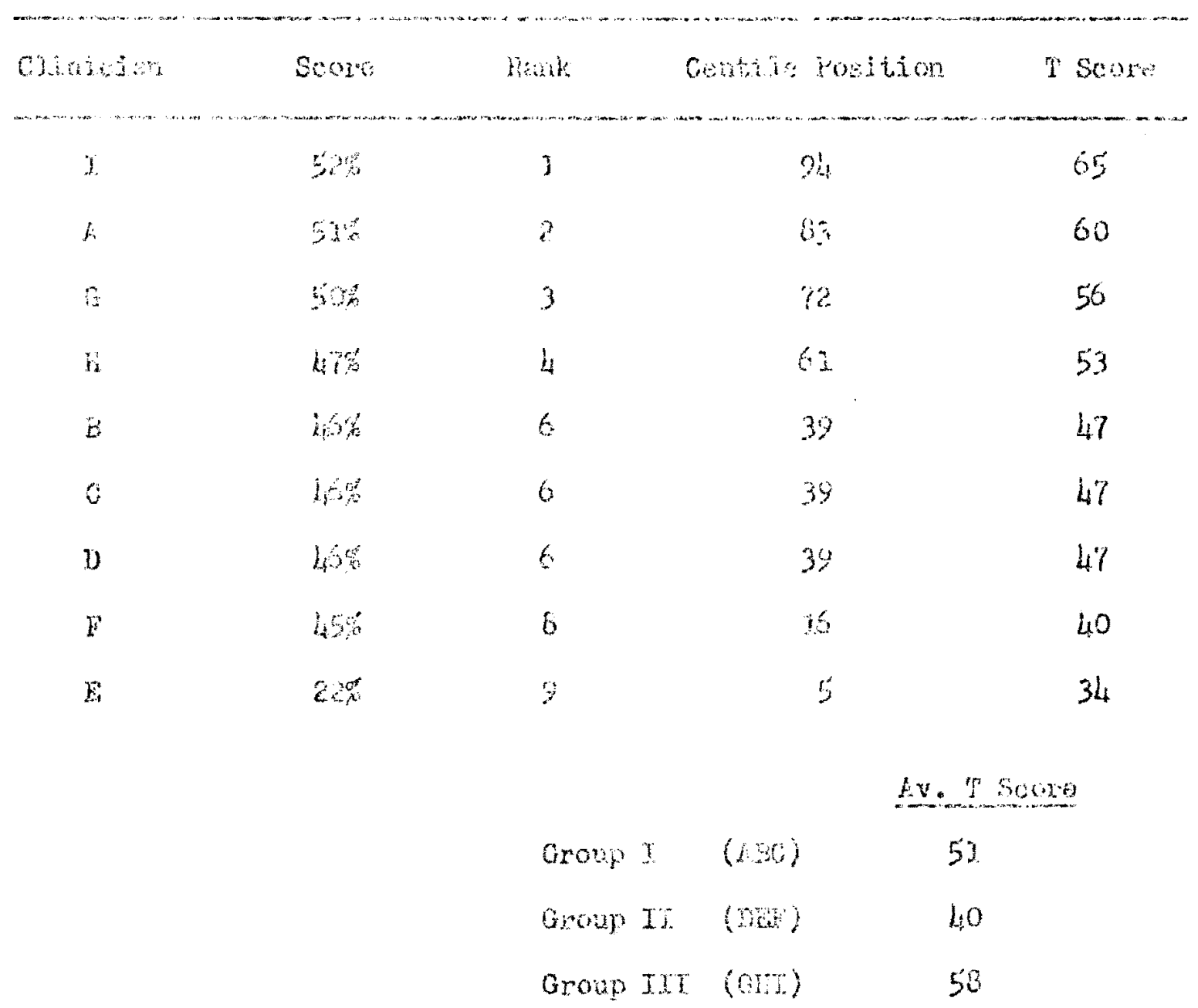


TABLE V

RANK ORDER ANLYSIS OF AMUTT UF GTIENMS VRRBAIZATRON

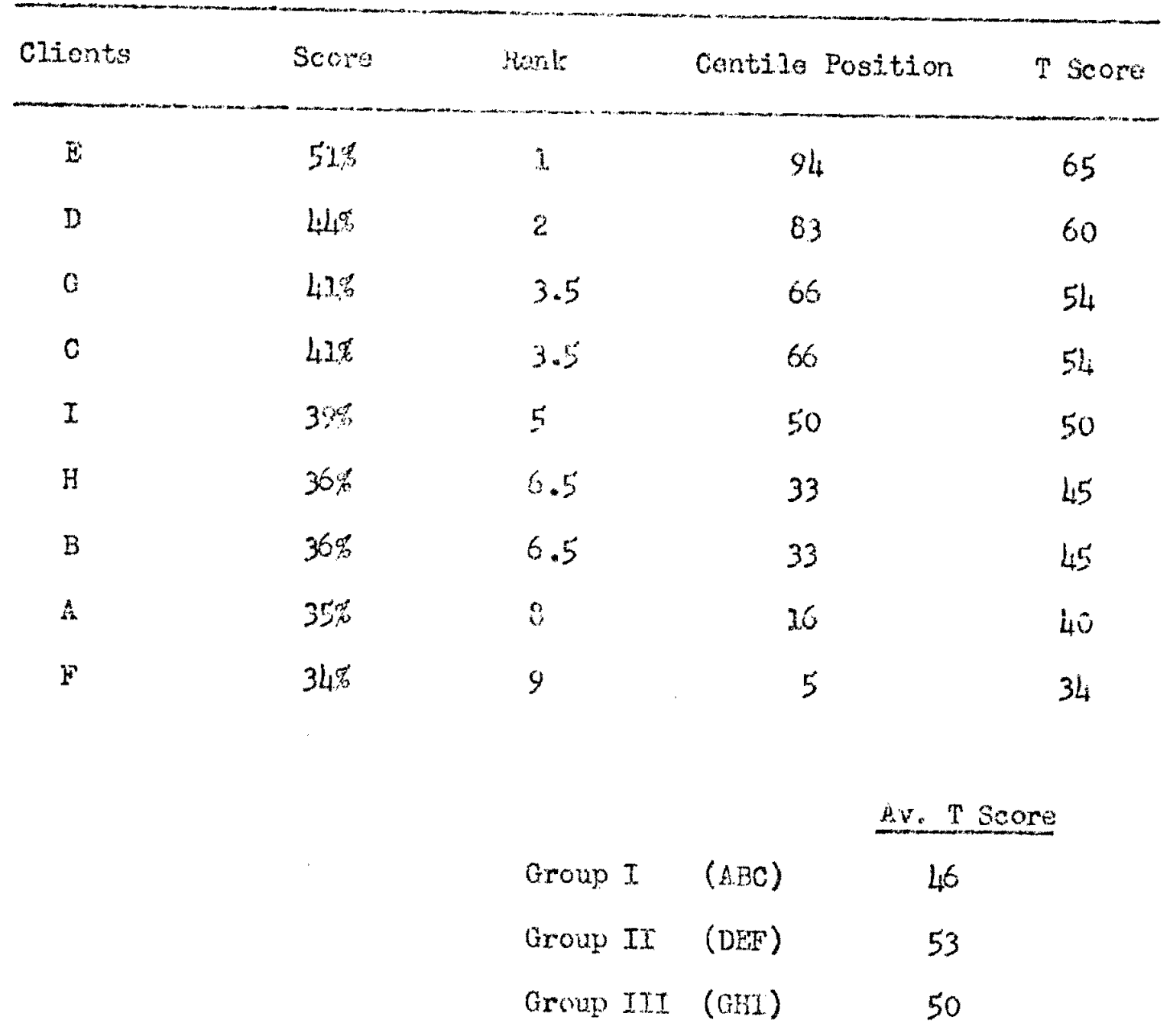


client varbalize more than the clinician. Note that $\mathrm{E}$ ranked fis in amount of clinician verbaljzations and 13 in amount of cjient verbalizations. Cornputation of the rank differonce correlation betweon clients' and clinicians' anount of verbalization rosizited in a coefficiont of $-2,20$.

Although a higher negative correlation might have been anticipated, the anount of silence involved probabjy influenced the results to some extent. line rank difference correlations between the amounts of verbalization and kinds of utierancos employed by the clinjoans can be seen in Table VI.

TARLE VI

BANK DIFFERSICE CORRELATION BETWEEN AMONN OF VERBALIZATION AND KINDS OF UTRERANCES USED BY T'HE CLTNICIANS

\begin{tabular}{|c|c|c|}
\hline Hirido of Ulierances & $\begin{array}{l}\text { Amount of Verbalization } \\
\text { Cinicians }\end{array}$ & $\begin{array}{l}\text { Used By } \\
\text { clients }\end{array}$ \\
\hline Positive & +.43 & +.07 \\
\hline Negative & -.04 & +.07 \\
\hline Descriptive & +.82 & +.03 \\
\hline Extraneous & -.63 & +.33 \\
\hline
\end{tabular}

There was a very high positive correlation, .82 , between the amount of verbalization used by the clinician and the use of descriptive utterances. A moderate but positive relationship was apparent betwean the cumount of verbalization and the use of positive utterances, while an apparentiy chance relationship existed between anount of verbalization and negativo utterences. A high negative rejatĩnship, -.63 , was indicated between the amount of verialization and oxtreneous ulterances. The amount of client verofization seemat to hear little relationship to the kinds of 
utiorances used by the clinician, since all the coufficients rovealed low positive correlations.

When tho kinds of uttemanes were subnitted to rank order analysis (see Tables VII, VIIT, IX and X), it wis fourd that Group $I$ tended to bo more positive, less negative and about, average in the descriptive and extraneous categories. Group II tended to use more extraneous ut terances, lass positive and descriptivo and about an zverage amount of negative utterances. Group III tended to use more negativa and descriptive utterances, fewer extraneous and an average amount of positive utterances. The author felt, however, that examination of the individual results proved to be more enlightoning.

It was noted that there was a wide variation between the scoras of the top-ranking cliniciar and the lowest ranking elinictan in both the positive and descriptive categories. Clinj.cian $G$ ranked highast in both categories while cliniaian $\mathrm{E}$ ranked lowost in both. In the extraneous category, E ranked highest wile $G$ ranked lowest. A further exanination of the tables showed that clinician $G$ tended to use a greatar armount of positive and descriptive utterances while using a lesser anount of negative and extraneous. Clinician $B_{s}$ on the other hand, used fewer positive and descrintive utterances while using more negative and extraneous. The pattern of kinds of utterances could be traced for each cliricta in a similar mannex.

\& rank difference correlation analysis between different kinds of utterances can be soen in rasle XI. 
TABCE TI

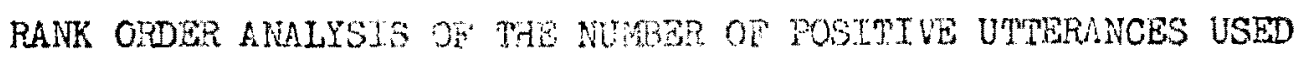

\begin{tabular}{|c|c|c|c|c|}
\hline Clinician & $\begin{array}{c}\text { Utterances prom mive } \\
\text { seore }\end{array}$ & Farik & Centile & T Seore \\
\hline$G$ & 5.0 & 1 & 94 & 66 \\
\hline $\mathrm{p}$ & 4.7 & 2 & 83 & 60 \\
\hline$A$ & 4.6 & 3 & 72 & 56 \\
\hline $\mathrm{B}$ & 4.4 & 4 & 61 & 53 \\
\hline$c$ & 2.3 & 5 & 50 & 50 \\
\hline$I$ & 2.0 & 6 & 39 & 48 \\
\hline$F$ & 1.8 & 7 & 28 & 45 \\
\hline $\mathrm{H}$ & .9 & 8 & 17 & 412 \\
\hline $\mathrm{E}$ & .7 & 9 & 5 & 34 \\
\hline & & & \multicolumn{2}{|c|}{ Av. $i$ score } \\
\hline & & & Group $\mathrm{X}$ & 53 \\
\hline & & & Group II & 46 \\
\hline & & & Group III & 52 \\
\hline
\end{tabular}




\section{FABLE VIIT}

RANK ORDER ANALYSIS OF THE NITHER OF WEUATIVE UTTERARCES USED

\begin{tabular}{|c|c|c|c|c|}
\hline Clinician & $\begin{array}{l}\text { Utterances per min. } \\
\text { Score }\end{array}$ & Rkarik & Centile & T Seore \\
\hline H & 1.0 & 1 & 94 & 66 \\
\hline$I$ & .7 & 2 & 83 & 60 \\
\hline 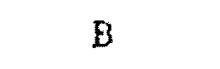 & .6 & 3.5 & 66 & 55 \\
\hline $\mathbf{E}$ & .6 & 3.5 & 66 & 55 \\
\hline$D$ & .5 & 5.5 & 44 & 49 \\
\hline$F$ & $\therefore$ & 5.5 & 44 & 49 \\
\hline G & .3 & 7.5 & 22 & 43 \\
\hline$c$ & .3 & 7.5 & 22 & 43 \\
\hline \multirow[t]{5}{*}{ A } & .2 & 9 & 5 & 34 \\
\hline & & \multicolumn{3}{|c|}{ Av. T Score } \\
\hline & & Group I & 14 & \\
\hline & & Group II & 51. & \\
\hline & & Group $1 Y$ Y & 56 & \\
\hline
\end{tabular}


Tit. PII ix

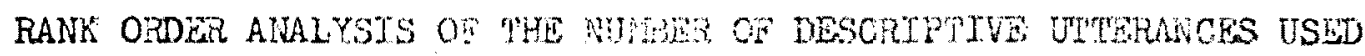

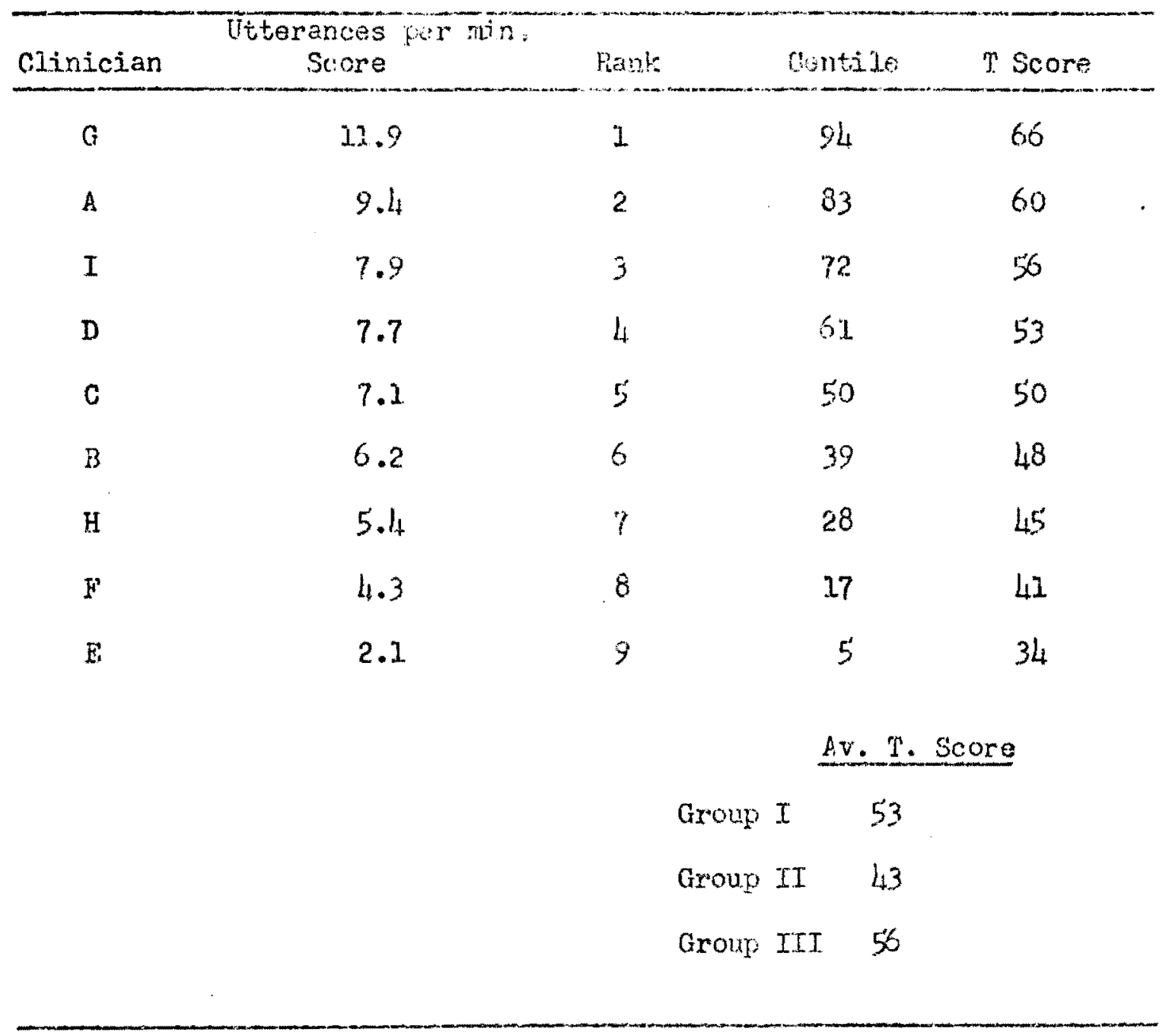




\section{ISHLE $Y$}

RANK ORDEK ANAIYSTS OP WHE NUMBIR OS EXTRANEOHS UTTERANCES USED

\begin{tabular}{|c|c|c|c|c|}
\hline Clinician & $\begin{array}{c}\text { Utterances per min. } \\
\text { Seore }\end{array}$ & Rank & Centile & T Score \\
\hline $\mathrm{E}$ & 2.4 & 3. & 94 & 65 \\
\hline$F$ & 2.0 & $\ldots 2$ & 83 & 60 \\
\hline $\mathrm{D}$ & 1.4 & 3 & 72 & 56 \\
\hline A & 1.2 & 4.5 & 55 & 52 \\
\hline $\mathrm{C}$ & 1.2 & 4.5 & 55 & 52 \\
\hline$I$ & .9 & 6 & 39 & 48 \\
\hline$B$ & .8 & 7 & 28 & 45 \\
\hline $\mathrm{H}$ & .5 & 8 & 17 & 41 \\
\hline \multirow[t]{5}{*}{$G$} & .4 & 9 & 5 & 34 \\
\hline & & & \multicolumn{2}{|c|}{ Av. I Score } \\
\hline & & & Group I & 50 \\
\hline & & & Group II & 61. \\
\hline & & & Group III & 41 \\
\hline
\end{tabular}


IABLE XI

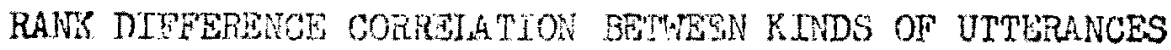

$\begin{array}{lc}\text { Kinds of Utterances } & \text { Correlation } \\ \text { Positive and Negative } & .61 \\ \text { Positive and Descriptive } & +.83 \\ \text { Positive and Bxtraneous } & -.40 \\ \text { Negative and Descriptive } & -.50 \\ \text { Negative and Extraneous } & -.10 \\ \text { Descriptive and Bxtraneous } & -.50\end{array}$

A high positive correlation could be seen between positjve and descriptive utterances, while all ather categories, except; negative and extraneous, showed a moderate negative relationship. Only a chance relationship existed between negative and extraneous. 
CHAPIEY V

CONCLUSJONS AND SUMNRY

In this investigation it seems that experience did not influence significsntly the amunt of verbalization used by the clinician ir speoch therapy. There did appear, however, to be a tendancy for the more experienced clinicians to talk more than the less experienced. In every instance but one, all the subjects talked more than tho students even though the amount of silence varied. It would appear that in the one instance whore results differed considerabiy from tho others (subject $E$ ), some other variable may have been presert. Perhaps tis type of technique used did not requjre nuch verbalization on the part of the subject. Since various techniques were used by the different subjects ranging from a game-oriented type of technique to a behavior modification program, the techniques used should be a variable worthy of further study.

It was apparent that the more verbal the clinician, the more positive and descriptive and the less negative and extraneous utterances she used. Yet, the kinds of utterances nsed did not appear to have much relationship to the amount of verbalization produced by the students. If the goal for therapy would be to have the children talk more, it seems the clinician should talk less. It seems, however, that not only the quantity of the elient's responses but the content of his responses would need to be taken into consideration in any evaluetion of the dinician's uge of certain kinds of utterances. A further study of the 


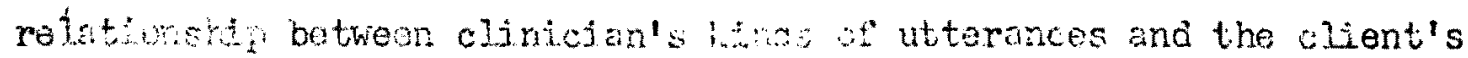
kinds oì resporses seems to be jndj cat ien.

Since groupirg the clinj cians resulted in a much too genoralized impression of the kinds of utterances useo, it would be of nore value to use Tables I and III to construct a profilo for each clinician individually. These profjles sar be seen in Table XIT. Such a profile could be valuable in furthe investigations.

TABIE XII

PRORTLES OF CLINTCIENS' VERBAIKATIONS

$A \quad B \quad C \quad$ C $\quad B \quad F \quad F \quad G \quad H \quad H \quad I$

Amount of verbalization per session $51 \%$ 16\% $46 \%$ 16\% $20 \%$ l5\% $50 \%$ 47\% $52 \%$

Amount of client verbalization per session $35 \%$ 35\% $43 \%$ 44\% 51\% $34 \%$ 41\% $36 \% \quad 39 \%$ Silence per session $24 \%$ 18\% $13 \%$ 20\% $27 \%$ \% $21 \%$ \% $17 \% \quad 9 \%$

Positive utterances

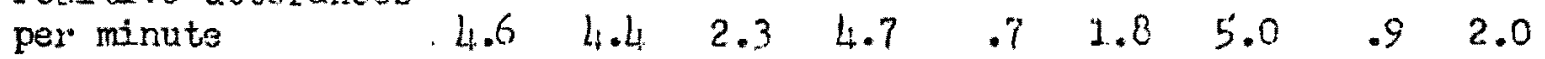

Negative utterances per minute $\begin{array}{lllllllll}.2 & .6 & .3 & .5 & .6 & .5 & .3 & 1.0 & .7\end{array}$

Descriptive utterances per minute $\begin{array}{lllllllll}9.4 & 6.2 & 7.1 & 7.7 & 2.1 & 4.3 & 11.9 & 5.4 & 7.9\end{array}$ Extraneous uster-.. $\begin{array}{lllllllllll}\text { ances per miriute } & 2.2 & .8 & 1.2 & 1.4 & 2.4 & 2.0 & .4 & .5 & .9\end{array}$ 
For instance, clinicha, $G$ ranked high in both the poitwo and descriptive categories and rolntively low th the negatwe and extraneous

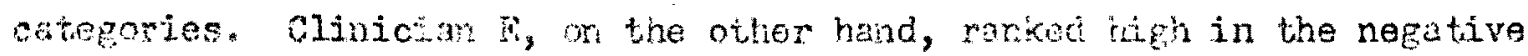
and extraneous categones and relatively low jn the positive and doscoptive. Depending on our critaria as to the dasirabiuty of using certaio kinds of language, we could make an evaluation concorning eacti clinician. Clinjeian $G$ tended to use moli mitive and descriptive language with few rogative or extrartons manto in har therapy approch. Clinician $\mathrm{E}$ tended to be more regative and to use more extraneous utberances whise usjne relatively few positive and descriptive utterances. Perhaps this kind az ovaluation migit be useful in suggesting ways os modifying clincian verbal behavion, and possihly improving the quality of therang sessions.

\section{SUMMARY}

A study was made of nine clinicians in a public school settirg. Six therapy sessions of each clinician were tapo-recorded and analyat, Fo deternine if experience were an important variable in the anount of verbalization used by the cliniciars and clients. An assossment was nece ano of the importance of this variable in the kinds of utterances ved vy the cliniclans.

Yt was found thet oxperience was not a significant variable in either of the two acuegries under study. It was shom, ringer, that there was a ne eative comrelation betweon tho amount of verbiajation of dinician and client. Ejght out of nine cliricians talked incre thar the clients. A high correlation was noted botwem the amount of verbaliation 
used by the clinictans and thetr use of postitve and descriptive utterances. The amount of cliar vathatiation seomed to bear little or no relationship to the kinds an ateraces usen ty the clinictan. Analysis of positive and cescriftive utterances showed a high positive correlation, while nost of tho otrer categories showed evidence of a moderate negative relationship.

Further study was suggested for the following:

(a) a survey of the difforent techniques used by clinicians

(b) the effect of different techniques on the amount of verbalization used by both clinician and client

(c) the modification of the content of the client's responses by the kinds of utterances used by the clinician.

The present study nay be of most value in indicating a possible means of constructing a nrofite of the kinds of utits rances used by each clinician. 
RTHRONOES

CHAPPLE, E., "The Interiction Chronograph; its erclution and present. application." Personnel, 25, 295-307 (1949).

GOLDMAN, H., and EISIER, F., "Individual differences between jnterviewers and thejr effect on interviewee's conversational behavior." J. Ment. Sci., $98,660-671$. (1952).

GUILroRD, J., Fundamental Statistics in Psychology and Education. $551-555$ New York: McGraw-Hill (1950).

KANCER, F. in DIXON, T. (Ed.), Verbal behavior and General Behavior Theory. 254-290 Englewood Cliffs: Prentice-Kall (1968).

KANFER, F., and McBREARTY, J., MMinimal social retrforcenent and inferview content." J. Clinical Psychology, 18, 210-215 (1.962).

KRASNER, I., "A techrique for investigating the relationship between the behavior cues of the examiner and the verbal behavion of the patient." I. Consult Paychology, 22, 364-356 (1958).

MATARAZZO, J. et al., "The Interaotion Chronchraph as an instrument for objective measurement of interaction patterns during interviews." J. Psychology, 44, 347-367 (1956).

MOWRER, D., Modification of Sueech Beravior: Ideas and Strategies for Students * Arizona Stata University (1969).

RHODES, R., SHAMES, G, and EGOLF, D., "An investigation of the verbel conditionjng of language themes in the rapeutic interviews with stutterers." Paper presented to A.S.H.A. Convention, Denver, $1,958$.

SASLOW, G., and MATARAZZO, J., "A Technique for Studying Changes in Iriterview Behavior." U. of Oregon Medical School. Research pâpar. 1950.

SKTNNER, B., Verbal Behavior. Ch. I. New York: Appleton-CenturymCrofts (1957).

SLOANS, H., and MACAULAY, B., Operant Frocedures in Femedial Speech and Language Training. Ch. I. Boston: Houghton Mifisin (1838). 


\section{AFPMNDX}

\section{TRANSCRIPT OF SHSSION \# 1 - SWCMENT \# 2 (CLTNICIAN G)}

\section{$\mathrm{D}$}

T. Look at me and say "sleep."

C. Sleep.

T. Let's get it to the front. Make your sound. Make your "g" sound. $\mathrm{D}$ "sleep."

C. Sleep.

T. Try it again.

c. Sleep.

T. again.

c. Sleep.

$P \quad D$

1. Good. Again.

C. Sleep.

P D D

T. good. Right down the front. Here we are. D

C\&T. Sleep.

$\mathrm{P} E \mathrm{E}$ I)

T. Very good. Five tallies. All right. Say "Sneezy was sleepy."

C. Sneezy was sleepy. $\mathrm{P} \quad \mathrm{F} \quad \mathrm{D}$

T. Good talking. What was -. tell me agair.

C. Sneezy was sleepy. D

T. Who was sloepy?

C. Sreezy

D)

T. Tell me about Sneezy.

c. He was sleepy. 
T.' Let's have sleepy dgain.

C. Sleepy.
$P$
$\mathrm{b}$
i)

T. Good. Five tallies. Say joir

C. " $r$ "

T. "nur"!

C. "nur"

D

T. "nurse"

C. "nurse"

$\mathrm{D}$

T. Say "nur"

c. "nur"

$P \quad D \quad D$

T. Right. Watch ne. "r"

C. "r"

D

T. "nur"

C. "nur"

T. Again. "nur."

C. "nur"

T. "nurse"

c. "nurse"

T. Good talking. "nurse"

C. "nurse"

T. "nurse"

C. "nurse"t

T. $\quad$ D $r "$

c. "ro"

T. Try "nur"

c. "nur" 
$\mathrm{D}$

1. "Again, "nur"

$\mathrm{T} \& \mathrm{C}$. "Wur"

T. \&. C. "Mur"

$P \quad E \quad D$

T. Good. 'inat's ten tajues. Now, I want hin to say "snow."

C. Snow.

D

x. Two times.

C. Snow, Snow.

$P \quad D$

T. Good, Again.

c. Snow

$P \quad D$

T. Good. Again.

c. Snow

T. Don't try to go too fast. Snow.

C. Snow

D $\quad$ D

T. It's a hard one. Snow. 


\section{TRANSCRTPT OF SESSION 22 - SERAENT H2 (CLINICIAN $H$ )}

T. No, that's what you're doing for me. What's the first thing you start to do? What would you like to say when I. say "II"?

C. "uI"

$N$

T. No, but before that, noise, what would you say?

c. "11

T. Make an "I" your way.

C. "I"

P D D

T. 0.K. She wants to do it her way. It sounds right, doesn't it? It D

sounds right for you to make it your old way, but we've learned a $D$

new noise instead. You've got to make the new nodse. Iut your

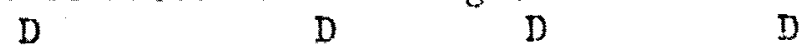

tongue up there .... "I". Up there. Open your: mouth, Steven. Don't $\mathrm{N} \quad \mathrm{D}$ D

you dare bite my ringer! Bight there. Put your tongue uo. Now turn on your voice. "I"

C. "I"

T. "I" Down here. "I"

C. "I"

T. $\mathrm{D}$

C. "1"

N D D

T. No. What did he do Fobbie? Could you see what he did?

C. Ho swallowed it. Swallowed i.t.

D D

T. He put his tongue down. How hold your tongue up on the roof of your D $\mathrm{E}$ mouth. "I". A1l rjght, Robbie nake ar "x" for me.

C. "r" 
T. Excuse mo, Steven make an "r" for me.

C. $" x "$

T. All right now pat your tongue to the front. "I"

C. "II"

T. Hold it up there, don't let it come cown. "I"

c. "I"

T. Hold it up there. Don't you dara lat that tongle go down. Do it. $D \quad D$ again. "l"

c. "I"

D D

T. Ali right. Now we're gojng to go " $\mathrm{r}$..." and we're going to stick "a" on the end of it.

C. $" r "-n "$

T. Again

c. " $-a^{n}$

N. No. A.ll right. "ra"

c. "ra"

T. "Oo". You do it.

c. "ra", "ra"

T. Perfect

C. "ra"

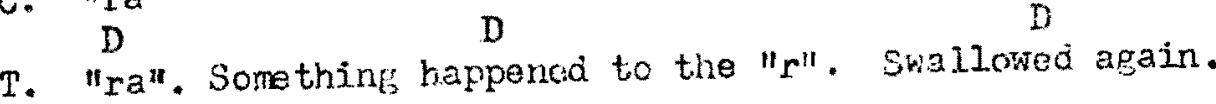

C. "ra"

N. D

T. No. "r"

c. $" r-a "$

D

$D$

T. No. Keep it together. Don't. let it separate. 


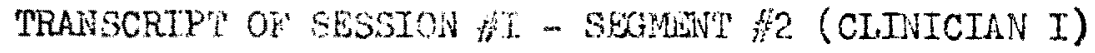

$\mathrm{B}$

T. Jerf, you weren't here the othor day. Iet's do your la, 1a, la.

C. Lá, 13,13 .

$\mathrm{P}$

T. Good: Can you think of sorething that has that sound in jt?

c. Irittle?

D $\quad$ s

T. Little; Good:

C. Nancy?

D N D D

T. Nancy? No, our tongue goss up on that. But jt isn't "I", It's "n". E

O.K. Let's take a picture, and see if we can find something that has $\mathrm{D}$

our sound. Now Don, Don and Rod ere just going to tell something

about the picture and Nicky, tall we khat is hapvening in the picturo N D $E$ D

here--not now--but when it's your tirn. 0.K. There's one.

E. $D$

Let's soe if the can tind ro for Paula. That is a goose.

D D D D D

Goose. This is a target. Pencil. Where do you haar the "l" in

"pencill" -- at the beginring, the middle or the end?

C. The end.
$P$
D

T. Right! Here's another one "See if you can figure out where the "I"

$\mathrm{D}$

is there. Nicky give ing your sond. Renember this sound when we

want somebody to be quiet? "sh"

C. "sh"

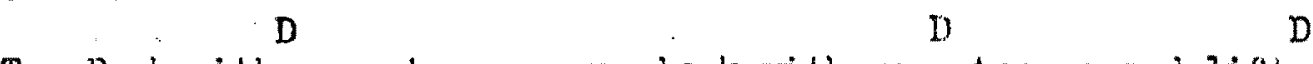

T. Back with your tongue, way back with your tongue and lift up.

c. "sh"

D

$D$

T. Bring yous tongue back. Bring your tongue way back. 
c. " $" s h "$

$\mathrm{P}$

T. That's a boy' There's what, we neat.

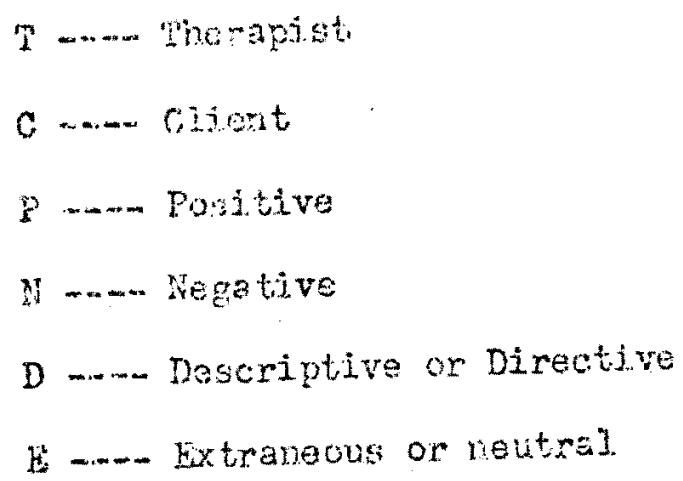

